\title{
FACTORS OF QUALITY MANAGEMENT SYSTEM INFLUENCING ORGANIZATIONAL PERFORMANCE: A STUDY OF PHARMACEUTICAL FACTORIES GETTING GMP CERTIFICATE IN VIETNAM
}

\author{
Nguyen Thuy Quynh Loan ${ }^{1, *}$ \\ ${ }^{1}$ Ho Chi Minh City University of Technology, Vietnam National University HCMC. \\ *Email: ntqloan@hcmut.edu.vn
}

(Received: April 05, 2016; Revised: April 20, 2016; Accepted: May 17, 2016)

\begin{abstract}
A study objective is to identify key factors of QMS (Quality Management System) influencing the organizational performance in pharmaceutical factories getting GMP (Good Manufacturing Practices) certificate. The original research model consists of eight independent factors (leadership, process management, education and training, supplier management, customer focus, employee involvement, product design, and continuous improvement) and three dependent factors related to organizational performance (productivity, product quality and customer satisfaction). The study collects 265 suitable questionnaires filled by middle managers or the top managers of the pharmaceutical factories getting GMP in Vietnam. The results identify key factors of QMS as leadership, employee involvement towards customer focus, and continuous improvement towards product design have positively impact to organizational performance that is represented by productivity and product quality, customer satisfaction. The study then suggests managerial implications to top management of pharmaceutical factories in improving performance through enhancing key factors of QMS implementation.
\end{abstract}

Keywords: GMP; organizational performance; QMS; pharmaceutical factories.

\section{Introduction}

Quality management philosophy in business practices is to satisfy customers, reduce costs, increase productivity, and enhance quality of outputs. Quality management practices help enhance business excellence (Lee et al., 2001). A number of quality management baselines exist that can result in an effective quality management system (QMS). They consist primarily of custom designed total quality management (TQM) programs, and programs built upon a nationally and internationally recognized standard (Schlickman, 2003). National standards consist of Malcom Baldrige in USA, Deming Award in Japan, and European Quality Award in Europe and so on. International standards are ISO 9001:2008, ISO 14000, Good Manufacturing Practices (GMP), SA 8000, and so on. GMP for pharmaceutical products is another practice of QMS that ensures that products are consistently produced and controlled to the quality standards based on the marketing authorization and product usage purpose. GMP is aimed primarily at diminishing the risks adherent in ant pharmaceutical production. In the concepts of quality assurance, GMP and quality control 
are interrelated aspects of quality management which are described and emphasized their relationship and fundamental importance to the production and control of pharmaceutical products (WHO, 2007).

After more than 15 years of GMP application, Vietnamese pharmaceutical industry has proved to be relatively competitive in the region. Many multinational pharmaceutical corporations have joined in Vietnam to expand their markets and supply chain. Vietnamese pharmaceutical industry recently developed rapidly, however it was lack of planning and less attention to upgrade high-tech industry for good quality products. Currently, getting GMP certificate of pharmaceutical factories is a mandatory requirement of the Vietnam Ministry of Health (Bo Y Te, 2010). To understand the role of GMP certificate in business practices, the objective of this paper is to identify the QMS factors influencing organizational performance of pharmaceutical factories getting GPM in Vietnam. This will support management to improve organizational performance in managing the key factors of QMS.

\section{Literature review and methodology}

\subsection{Literature review} QMS Factors

A quality management system (QMS) is a company's objective and process that design to meet the customer satisfaction. It contents organizational structure, procedures, processes, resources and continuous improvement. Quality management system is a powerful tool, which enables every organization to increase quality of products and/or services offered through continuous improvement of processes (CERCO, 2000).

The underlying principles of QMS consist of eight core principles as Customer focus, Leadership, Involvement of people, Process approach, System approach to management, Continuous improvement, Factual approach to decision making, Mutually beneficial supplier relationships (Jaafreh et al., 2012; Jorgensen et al., 2013). The study of Arumugam et al. (2011) identified that there are many factors of TQM that are effective factors in improving performance: leadership, customer focus, training, supplier quality management, product design, process management, and teamwork. The GMP is a part of QMS and good safety and hygiene to control the condition of facility, people and control the process. Eight basic factors about quality management in GMP are defined customer focus, leadership, employee contribution, process approach, system method, continuous improvement, supplier management and factual based decision.

\section{Organizational performance}

There were many different ideas regarding the organizational performance. The productivity and product quality were indicators of organizational performance (Ali et al., 2013). Besides that, customer satisfaction was also measured as organizational performance (Abdullah et al., 2009; Agus et al., 2009). Profitability, cost reduction and market share growth were measurement of organizational performance (Jorgensen et al., 2013; Kaynak, 2003). The success of implementing quality management system leads improving organizational performance as product quality, productivity and customer satisfaction (Demirbag et al., 2006; Feng et al., 2008; Nekoueizadeh et al., 2013; Yuparkon et al., 2013). Thus, organizational performances in this paper are measured by productivity, product quality and customer satisfaction.

\section{Relationship between QMS factors and organizational performance \\ Leadership}

Leadership is a strong commitment from the top management in quality management and leading to higher quality performance. Their commitment is one of the 
critical determinants of successful TQM implementation. Leadership practices promote quality and high performance through creating and maintaining the involvement of both internal (staff) and external (customers and suppliers) people to achieve the organization's goals (Nguyen, 2004). Leadership can be communication of the mission and vision throughout the entire organization, acceptance of quality responsibility by top management, evaluation of top management on quality, participation by top management in quality improvement efforts, specificity of quality goals. It can also be importance attached to quality in relation to cost and schedule, comprehensive quality planning, management's commitment to quality through communication with employees, participation of managers in quality activities and contribute improvements (Saraph et al., 1989). The leadership was the strongest significant predictors of operational performance (Samson et al., 1999; Kanapathy et al., 2012; Jaafreh et al., 2012). Thus, the following hypothesis was suggested:

H1: Leadership positively influences organizational performance.

\section{Process management}

A desired result is achieved more efficiently when activities and related resources are managed as a process (Nguyen, 2004). In the EFQM Excellence Model and King Abdullah II Award, the process management is defined as "how the organization designs, manages and improves its processes in order to support its policy and strategy and fully satisfy, and generate increasing value for, its customers and other stakeholders" (KAAPS, 2010; EFQM, 2010). According to Saraph et al. (1989), the activities of process management are clarity of process ownership, boundaries, and steps, less reliance on inspection, use of statistical process control, employee self-inspection, automatic testing. Process management will reduce process variation for increasing output consistency, reducing rework and waste and resulting in an increased percent-passed final inspection with no rework. The process management influences the operational performance, especially in improving product quality, productivity of the firms (Nekoueizadeh et al., 2013, Kanapathy, 2008). Thus, the following hypothesis is offered:

H2: Process management positively influences organizational performance.

\section{Education and training}

Training is one of the most important requirements in a successful TQM implementation. Delivery of high quality services and products requires that employees be equipped with knowledge and skills. All management personnel, supervisors, and employees should accept quality education and training. Training helps employees at all levels to understand the quality management system and their roles and responsibilities within it. General training level in the basic aspects of quality includes both managers and employees. There are provision of statistical training, trade training, and quality-related training for all employees (Jamali et al., 2010). Many authors conducted the research of identifying the success factor in implementing quality system as TQM, ISO and QMS in which resulted that education and training are one of the most important elements in a successful implementation and organizational growth (Agus et al., 2009). Therefore, it is hypothesized that:

H3: Education and training positively influence organizational performance.

\section{Supplier management}

Quality is more important factor than price in selecting suppliers. Long-term relationship with suppliers has to be established and the company has to collaborate with supplier to help improve the quality of products/ services (Nguyen, 2004). The effective supplier management is fewer dependable suppliers, reliance on supplier 
process control, strong interdependence of supplier and customer, purchasing policy emphasizing quality rather than price, supplier quality control and assistance in product development (Saraph et al., 1989). The providing feedback on quality performance to supplier is highly concentrated to identify the corrective action and preventive action that resulted to improve the organizational performance (Saraph et al., 1989; Demirbag, 2006). Therefore, it is hypothesized that:

H4: Supplier management positively influences organizational performance.

\section{Customer Focus}

The organization is driven by customer's needs. It is necessary to identify these needs and their level of satisfactions. The establishment and maintenance of customer relationship is very important missions to organization (Nguyen, 2004). The involvement of employee in term of customer focus is able to respond and adapt to changing customer demand and expectations, it shows the important of all employees in the organization to give their commitment to establishing and sustaining a high level of customer satisfaction. Understanding, satisfying and surpassing customer needs and expectations is the primary goal of each organization (Jamali et al., 2010). Therefore, it is hypothesized that:

H5: Customer focus positively influences organizational performance.

\section{Employee Involvement}

Employee involvement is of crucial importance to TQM as a vital means to achieve customer satisfaction, delight and commitment through continuous quality improvement. Employee involvement shows the participants and contributions of all people in the organization, from top to bottom direction (Nguyen, 2004). It can be implementation of employee involvement and quality circles, open employee participation in quality decisions, responsibility of employees for quality, employee recognition for superior quality performance, and effectiveness of supervision in handling quality issues, ongoing quality awareness of all employees (Saraph et al., 1989). Employee participation in monitoring, detecting, and correcting quality problems requires decentralization and delegation in organizations (Kaynak, 2003). By personally participating in quality improvement activities, employees acquire new knowledge, see the benefits of the quality disciplines, and obtain a sense of accomplishment by solving quality problems (Abdullah et al. 2009). Thus, a hypothesis is proposed as:

H6: Employee involvement positively influences organizational performance.

\section{Product design}

Design is recognized as a major determinant of quality (Fynes et al., 2005). Effective design leads to high level of customer satisfaction. The activities relating to product design are involvement of all affected departments in design reviews, emphasis on productivity, clarity of specifications, and emphasis on quality, not roll-out schedule, avoidance of frequent redesigns (Saraph et al., 1989). Product design requires a wide range of information, design teams are comprised of people from purchasing, design, production, suppliers and customers The product development by creative/quality innovation significantly and positively impacts organizational performance (Flynn et al., 1995). The consumer perception on the product innovation as stronger, more favourable and unique are found to be important moderators in the relationship between product development by innovation and organizational performance. The study of Udegbe et al. (2013) mentioned that product development had a positive influence organizational performance. Thus, the following hypothesis is offered:

H7: Product design positively influences organizational performance. 


\section{Continuous improvement}

Continuous improvement means a commitment to constant examination of the technical and administrative process in search of better methods. Continuous improvement is a permanent objective of the organization (Nguyen, 2004). This factor has showed a significant and positive effect on increasing market opportunities and reduction in waste of resources. The continuous improvement and innovation, which is the most important part of services, means searching for never-ending improvements and developing processes to find new or improved methods in the process of converting inputs into useful outputs (Talib et al., 2010). Therefore, it is hypothesized that:

H8: Continuous improvement positively influences organizational performance.

\section{Research model}

Based on the relationships above, a research model is shown in Figure 1. There are eight independent factors as leadership, process management, education and training, supplier management, continuous improvement, customer focus and employee involvement, product design. The dependent factor is organizational performance measured by productivity, product quality and customer satisfaction.

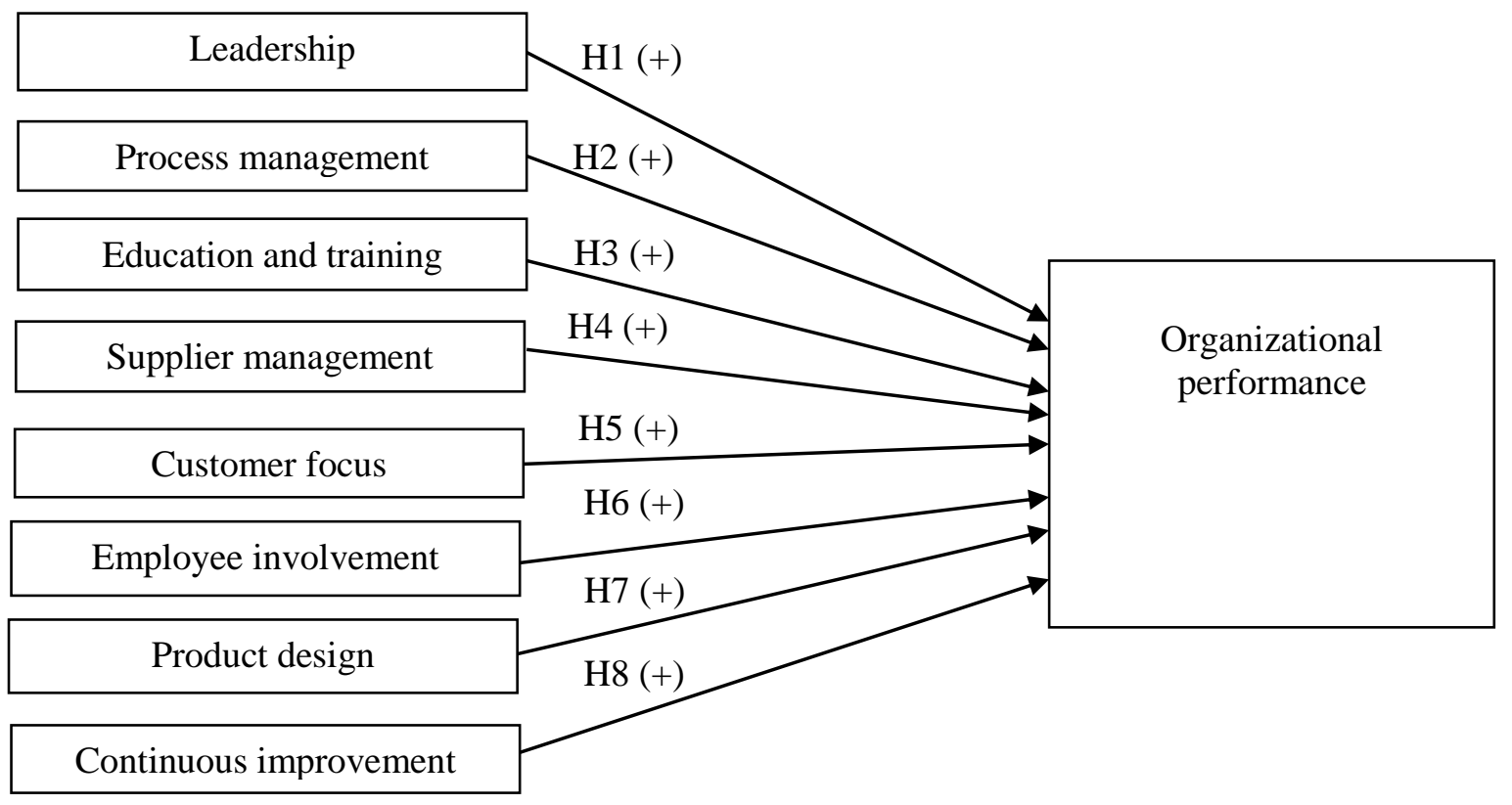

Figure 1. Research model

\subsection{Methodology}

The study consists of two stages: preliminary study and formal study. Preliminary study was conducted using the qualitative approach. The draft questionnaires were developed from literature review to find out the relevant constructs. The in-depth interview with the preliminary questionnaire was conducted on top directors and managers of the Vietnamese pharmaceutical factories. In fact, five respondents of five pharmaceutical factories (Savipharm, Stada, Nhat Nhat, BV
Pharma and Imexpharm) were selected for indepth interviews to adjust the content and wording, and to add more items of constructs relevant to Vietnamese context. After qualitative research, the questionnaires were revised to suitable for survey at pharmaceutical factories in Vietnam.

Quantitative research was implemented in the stage of formal study. The closed questionnaires were used to survey. Revised measurement scales consisted of 45 items, in which eight independent factors were 33 items 
and three dependent variables were 12 items (Table 1). The minimum sample size was planed $225(=45 \times 5)$. There are about 170 pharmaceutical factories getting GMP certificate in Vietnam. Due to limitation of relationship with all factories, the study was conducted at pharmaceutical factories getting GMP certificate located in the Southern Vietnam. The respondents were middle or top managers that have worked at different divisions of factories. Thus, the questionnaires were sent to 50 factories and about five to ten questionnaires was collected at each factory. The techniques as Cronbach's alpha, Exploratory Factor Analysis (EFA) are used to test the reliability of measurement scale. Multiple Regressions is used for hypotheses testing.

Table 1. The revised measurement scale

\begin{tabular}{|c|c|c|}
\hline Factors & Items & Sources \\
\hline \multicolumn{3}{|c|}{ Leadership } \\
\hline LS1 & $\begin{array}{l}\text { Leaders take on the responsibility for developing quality } \\
\text { oriented management systems. }\end{array}$ & Santos et al. (2007) \\
\hline LS2 & $\begin{array}{l}\text { Leaders allocate resources for continuous improvement of the } \\
\text { management system. }\end{array}$ & Santos et al. (2007) \\
\hline LS3 & Management team always cares to customer demand. $(*)$ & Qualitative research \\
\hline LS4 & $\begin{array}{l}\text { Senior managers actively encourage the changes and } \\
\text { implementation about a culture of trust, involvement, and } \\
\text { commitment in moving towards 'Best Practice' }\end{array}$ & Samson et al. (1999) \\
\hline LS5 & $\begin{array}{l}\text { Leaders listen, support, and encourage employees to take part } \\
\text { in deciding and managing total quality policies and plans. }\end{array}$ & Santos et al. (2007) \\
\hline LS6 & $\begin{array}{l}\text { Top management empowers employees to solve quality } \\
\text { problems }\end{array}$ & Santos et al. (2007) \\
\hline \multicolumn{3}{|c|}{ Process management } \\
\hline PR7 & $\begin{array}{l}\text { Processes are designed to ensure that skills and capacities } \\
\text { meet company needs. }\end{array}$ & Santos et al. (2007) \\
\hline PR8 & Standardized and clear work or process instructions are given & Samson et al. (1999) \\
\hline PR9 & $\begin{array}{l}\text { Process capability and productivity are regularly assessed the } \\
\text { effectiveness of processes and production operation. }\end{array}$ & Zhang (1999) \\
\hline PR10 & $\begin{array}{l}\text { Organization closely works with suppliers to improve } \\
\text { processes. }\end{array}$ & Samson et al. (1999) \\
\hline \multicolumn{3}{|c|}{ Education and training } \\
\hline ED11 & Employees are encouraged to accept education and training. & Zhang (1999) \\
\hline ED12 & $\begin{array}{l}\text { Most employees are trained on how to use quality } \\
\text { management methods. }\end{array}$ & Zhang (1999) \\
\hline ED13 & $\begin{array}{l}\text { Specific work-skills training (technical and vocational) are } \\
\text { given to employees. }\end{array}$ & Antony (2002) \\
\hline ED14 & The top management pays attention to employee training. $(*)$ & Qualitative research \\
\hline
\end{tabular}




\begin{tabular}{|c|c|c|}
\hline \multicolumn{2}{|c|}{ Supplier management } & \multirow[b]{2}{*}{ Antony (2002) } \\
\hline SM15 & $\begin{array}{l}\text { There are technical assistances to improve the quality and } \\
\text { responsiveness of suppliers. }\end{array}$ & \\
\hline SM16 & Clarity of specifications is provided to suppliers. & Santos et al. (2007) \\
\hline SM17 & The suppliers involve in the product development process. & Antony (2002) \\
\hline SM18 & $\begin{array}{l}\text { Organization has established long-term co-operative relations } \\
\text { with suppliers. }\end{array}$ & Santos et al. (2007) \\
\hline \multicolumn{2}{|c|}{ Customer Focus } & \\
\hline CF19 & $\begin{array}{l}\text { Organization always conducts market research in order to } \\
\text { collect suggestions for improving products. }\end{array}$ & Zhang (1999) \\
\hline CF20 & $\begin{array}{l}\text { The requirements of customers are effectively disseminated } \\
\text { and understood throughout the workforce. }\end{array}$ & Samson et al. (1999) \\
\hline CF21 & $\begin{array}{l}\text { Organization receives and responds to customer's needs and } \\
\text { feedback on products/ services provided quickly. }\end{array}$ & Zhang (1999) \\
\hline \multicolumn{2}{|c|}{ Employee Involvement } & \\
\hline $\mathrm{EI} 22$ & $\begin{array}{l}\text { Employees understand the importance of their contribution } \\
\text { and role in the organization. }\end{array}$ & Samson et al. (1999) \\
\hline EI23 & $\begin{array}{l}\text { Employees willingly share their knowledge and experience. } \\
(* *)\end{array}$ & Qualitative research \\
\hline EI24 & $\begin{array}{l}\text { Employees actively seek opportunities to enhance their } \\
\text { competence, knowledge and experience. }(* *)\end{array}$ & Qualitative research \\
\hline EI25 & $\begin{array}{l}\text { Employees joint in teams or groups to improve quality or } \\
\text { solve problems. }(* *)\end{array}$ & Qualitative research \\
\hline \multicolumn{2}{|c|}{ Product Design } & \\
\hline PD26 & Product/service specifications and procedures are clarified. & Antony (2002) \\
\hline PD27 & $\begin{array}{l}\text { The customer requirements are thoroughly considered in new } \\
\text { product design }\end{array}$ & Zhang (1999) \\
\hline PD28 & $\begin{array}{l}\text { New product designs are thoroughly reviewed before } \\
\text { production. }\end{array}$ & Zhang (1999) \\
\hline PD29 & Various departments participate in new product development. & Zhang (1999) \\
\hline \multicolumn{2}{|c|}{ Continuous Improvement } & \\
\hline CI30 & $\begin{array}{l}\text { Improvement of products/services is based on customer } \\
\text { demand. }(* *)\end{array}$ & Qualitative research \\
\hline CI31 & $\begin{array}{l}\text { There are assessment and improvement of processes and } \\
\text { products/services. }\end{array}$ & Antony (2002) \\
\hline CI32 & $\begin{array}{l}\text { Feedback is provided to employees on their quality } \\
\text { performance }\end{array}$ & Antony (2002) \\
\hline CI33 & There are programs on waste elimination. & Antony (2002) \\
\hline
\end{tabular}




\begin{tabular}{|l|l|l|}
\hline Productivity & \\
\hline PT34 & Waste and costs in activities of production are decreased. & Santos et al. (2007) \\
\hline PT35 & The cycle time is reduced. & Santos et al. (2007) \\
\hline PT36 & $\begin{array}{l}\text { Organization achieves rationalization of process and } \\
\text { procedure. } * *)\end{array}$ & Qualitative research \\
\hline Product & Quality & \\
\hline PQ37 & Conformity rates of primary products are increased. & Zhang (1999) \\
\hline PQ38 & Failure rates of primary products are decreased. & Zhang (1999) \\
\hline PQ39 & Quality level of primary products is increased. & Zhang (1999) \\
\hline PQ40 & Reliability of primary products is increased. & Zhang (1999) \\
\hline Customer satisfaction & Satisfaction of clients is improved. & Santos et al. (2007) \\
\hline CS41 & Client perception is improved. & Santos et al. (2007) \\
\hline CS42 & The number of customer complaints is reduced. & Santos et al. (2007) \\
\hline CS43 & Santos et al. (2007) \\
\hline CS44 & Communication with clients is improved. & Santos et al. (2007) \\
\hline CS45 & Consolidation and loyalty of clients is increased. &
\end{tabular}

Note: Items $(*)$ are adjusted and items $(* *)$ are developed in qualitative research.

\section{Result and discussion}

\section{Sample description}

More than 350 questionnaires were sent for survey. There were 265 suitable questionnaires are used for analysis. The table 2 describes the main characteristics of the sample.

Table 2. Sample descriptive statistics

\begin{tabular}{|c|c|c|c|c|c|}
\hline Description & Frequency & Percent $(\%)$ & Description & Frequency & Percent (\%) \\
\hline \multicolumn{3}{|l|}{ Ownership } & \multicolumn{3}{|l|}{ Position of respondent } \\
\hline State-owned & 0 & - & General manager (GM) & 0 & - \\
\hline Foreign & 6 & 12.0 & Vice GM & 1 & 0.4 \\
\hline Joint venture & 3 & 6.0 & Director & 11 & 4.2 \\
\hline Joint stock & 41 & 82.0 & Vice director & 7 & 2.6 \\
\hline Total & 50 & 100.0 & Manager & 115 & 43.4 \\
\hline \multicolumn{3}{|c|}{ Number of employees } & Vice manager & 37 & 14.0 \\
\hline$\leq 100$ & 4 & 8.0 & Group leader & 82 & 30.9 \\
\hline $101-300$ & 32 & 64.0 & Vice group leader & 12 & 4.5 \\
\hline $301-500$ & 11 & 22.0 & Total & 265 & 100.0 \\
\hline$>500$ & 3 & 6.0 & & & \\
\hline Total & 50 & 100.0 & & & \\
\hline
\end{tabular}




\section{Cronbach's Alpha and EFA Testing}

The Cronbach's Alpha reliability analysis is a measurement of the internal consistency of the constructed items to assess the reliability of each factor in measurement scales. The reliability of Cronbach's Alpha shows how relation of the items in a set which are significantly correlated with the other as well. Such coefficient that is above 0.6 is acceptable for the reliability of each factor and the item-total correlation that is smaller than 0.4 is considered to be deleted (Hair et al., 2006). The result of reliability analysis in this study indicates that all of measurement scales (45 items) are reliable (Table 3).

Exploratory factor analysis (EFA) is used to test the validity of measurement scales by using the principal axis factoring with Promax rotation. The criteria for the validity of EFA are Eigenvalue $\geq 1$, The Accumulative of Total Variation Explained $\geq 50 \%$, and Factor Loadings $\geq 0.50$. The summary of reliability analysis and EFA in the Table 3 proves that all of measurement scales are reliable and valid.

After refining EFA, supplier management factor was removed. This could be explained that the involvement levels of Vietnamese suppliers in pharmaceutical industry are low. Due to almost active ingredients were imported, they were limited of sharing $R \& D$, IP protection as well as buyer power in the context of generic product competition. Two factors as "customer focus" and "employee involvement" were extracted into one factor. It could be understand that the employees with their competency, knowledge and contribution are considered as key drivers to proactively deliver high quality of product/service to customers. Therefore, it was named employee involvement towards customer focus. Two other factors as "product design" and "continuous improvement" were also extracted one factor. Product design factor was understood by respondents in term of how to improvement and develop product to adapt with customer demand and expectation. Thus, this combined factor was named continuous improvement towards product design. For dependent factors, two factors as "productivity" and "product quality" were extracted into one factor, namely "productivity and product quality".

Table 3. Summary of Cronbach's Alpha and EFA results

\begin{tabular}{|c|c|c|c|c|}
\hline \multirow{2}{*}{ Factors } & \multirow{2}{*}{$\begin{array}{l}\text { Cronbach's } \\
\text { alpha }\end{array}$} & \multicolumn{2}{|c|}{ After EFA } & \multirow{2}{*}{$\begin{array}{l}\text { Factor } \\
\text { loading }\end{array}$} \\
\hline & & Eliminate & Accept & \\
\hline \multicolumn{5}{|c|}{$\begin{array}{l}\text { Independent factors: } \\
\mathrm{KMO}=0.905 \text {, Cumulative } \% \mathrm{TVE}=60.279 \% \text {, Eigenvalues }=1.085\end{array}$} \\
\hline Leadership & 0.831 & $\begin{array}{l}3 \text { (LS4, LS5, } \\
\text { LS6) }\end{array}$ & $\begin{array}{l}3(\mathrm{LS} 1, \mathrm{LS} 2 \\
\mathrm{LS} 3)\end{array}$ & $\begin{array}{c}0.542 \div \\
0.842\end{array}$ \\
\hline Process management & 0.735 & 1(PR9) & $\begin{array}{l}3(\mathrm{PR} 7, \mathrm{PR} 8 \\
\quad \mathrm{PR} 10)\end{array}$ & $\begin{array}{c}0.533 \div \\
0.714\end{array}$ \\
\hline $\begin{array}{l}\text { Education and } \\
\text { training }\end{array}$ & 0.780 & 1 (ED13) & $\begin{array}{l}3(\mathrm{ED} 11, \mathrm{ED} 12, \\
\mathrm{ED} 14)\end{array}$ & $\begin{array}{c}0.579 \div \\
0.781\end{array}$ \\
\hline Supplier management & 0.781 & $\begin{array}{l}4(\mathrm{SM} 15, \mathrm{SM} 16 \\
\mathrm{SM} 17, \mathrm{SM} 18)\end{array}$ & 0 & - \\
\hline Customer focus and & 0.676 and & 0 & 7 (CF19, CF20, & $0.534 \div$ \\
\hline
\end{tabular}




\begin{tabular}{|c|c|c|c|c|}
\hline \multirow{2}{*}{ Factors } & \multirow{2}{*}{$\begin{array}{l}\text { Cronbach's } \\
\text { alpha }\end{array}$} & \multicolumn{2}{|c|}{ After EFA } & \multirow{2}{*}{$\begin{array}{l}\text { Factor } \\
\text { loading }\end{array}$} \\
\hline & & Eliminate & Accept & \\
\hline $\begin{array}{l}\text { Employee } \\
\text { involvement }\end{array}$ & 0.774 & & $\begin{array}{c}\text { CF21, EI22, } \\
\text { EI23, EI24, EI25) }\end{array}$ & 0.764 \\
\hline $\begin{array}{l}\text { Product design and } \\
\text { Continuous } \\
\text { improvement }\end{array}$ & $\begin{array}{l}0.789 \text { and } \\
0.828\end{array}$ & 1 (PD26) & $\begin{array}{c}7 \text { (PD27, PD28, } \\
\text { PD29, CI30 } \\
\text { CI31, CI32 } \\
\text { CI33) }\end{array}$ & $\begin{array}{c}0.546 \div \\
0.760\end{array}$ \\
\hline \multicolumn{5}{|c|}{$\begin{array}{l}\text { Dependent factors: } \\
K M O=0.905, \text { Cumulative } \% T V E=60.279 \%, \text { Eigenvalues }=1.085\end{array}$} \\
\hline $\begin{array}{l}\text { Productivity and } \\
\text { Product quality }\end{array}$ & $\begin{array}{l}0.734 \text { and } \\
0.815\end{array}$ & 0 & $\begin{array}{c}7 \text { (PT34, PT35, } \\
\text { PT36, PQ37, } \\
\text { PQ38, PQ30, } \\
\text { PQ40) }\end{array}$ & $\begin{array}{c}0.518 \div \\
0.778\end{array}$ \\
\hline Customer satisfaction & 0.840 & 0 & $\begin{array}{c}5(\mathrm{CS} 41, \mathrm{CS} 42 \\
\mathrm{CS} 43, \mathrm{CS} 44 \\
\mathrm{CS} 45)\end{array}$ & $\begin{array}{c}0.521 \div \\
0.867\end{array}$ \\
\hline
\end{tabular}

\section{Revised research model}

As a result, a revised research model (Figure 1) consisted of five independent factors (leadership, process management, education and training, continuous improvement towards product design, employee involvement towards customer focus) and two dependent factors (productivity and product quality, customer satisfaction).

Based on Figure 1, the revised hypotheses were adjusted as follows:

Model 1 (dependent factor: Productivity and product quality):

Hla: Leadership positively influences productivity and product quality.

H2a: Process management positively influences productivity and product quality.

H3a: Education and training positively influences productivity and product quality.

H4a: Employee involvement towards customer focus positively influences productivity and product quality.

H5a: Continuous improvement towards product design positively influences productivity and product quality.

Model 2 (dependent factor: customer satisfaction):

H1b: Leadership positively influences customer satisfaction.

H2b: Process management positively influences customer satisfaction.

$H 3 b$ : Education and training positively influence customer satisfaction.

H4b: Employee involvement towards customer focus positively influences customer satisfaction.

H5b: Continuous improvement towards product design positively influences customer satisfaction. 


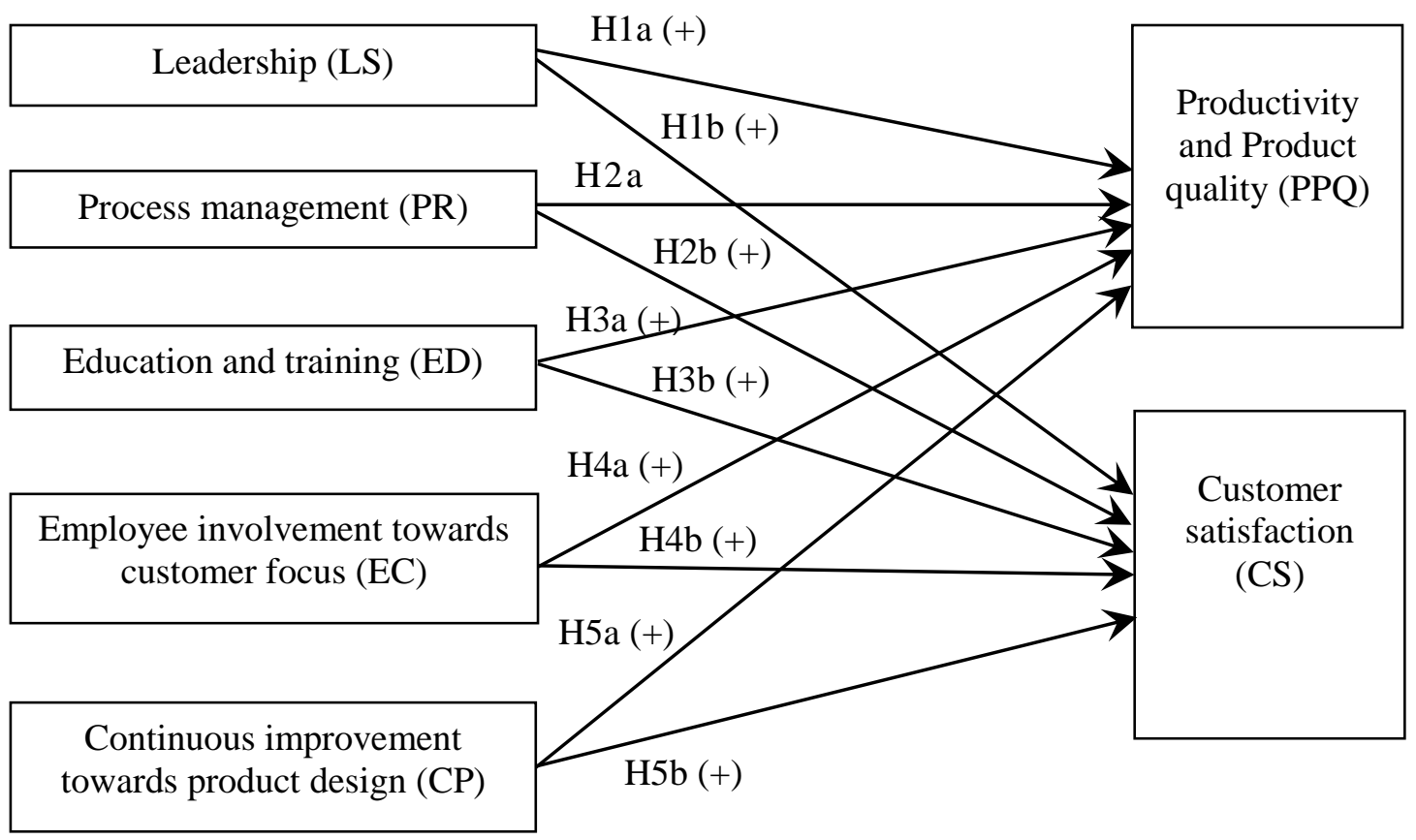

Figure 2. Revised research model

\section{Pearson Correlation}

The Pearson Correlation (Table 4) showed that independent factors (LS, PR, ED, $\mathrm{EC}, \mathrm{CP})$ have significant correlations to the dependent factors (PPQ and CS). However, a correlation between those independent variables may influence the regression analysis results due to multicolinearty. It will be tested after regression analysis by Variance Inflation Factor (VIF).

Table 4. Pearson Correlation

\begin{tabular}{|l|l|c|c|c|c|c|}
\hline \multicolumn{2}{|c|}{} & LS & PR & ED & EC & CP \\
\hline \multirow{4}{*}{ PPQ } & Pearson Correlation & $.528^{* *}$ & $.389^{* *}$ & $.357^{* *}$ & $.509^{* *}$ & $.704^{* *}$ \\
\cline { 2 - 7 } & Sig. (2-tailed) & .000 & .000 & .000 & .000 & .000 \\
\cline { 2 - 7 } & N & 265 & 265 & 265 & 265 & 265 \\
\hline \multirow{3}{*}{ CS } & Pearson Correlation & $.565^{* *}$ & $.437^{* *}$ & $.387^{* *}$ & $.540^{* *}$ & $.572^{* *}$ \\
\cline { 2 - 7 } & Sig. (2-tailed) & .000 & .000 & .000 & .000 & .000 \\
\cline { 2 - 7 } & N & 265 & 265 & 265 & 265 & 265 \\
\hline
\end{tabular}

\section{Multiple regression analysis}

The Model 1 is significant $($ Sig. value = 0.000). The adjusted R-square is 0.554. It illustrates that the independent factors explain $55.4 \%$ of the variance of dependent factor (PPQ). In model 1 (Table 5), continuous improvement towards product design has strongest impact on productivity and product quality $(\beta=0.536)$, follow by leadership ( $\beta=$ 0.249 ) and employee involvement towards customer focus $(\beta=0.135)$.

The Model 2 is also significant $($ Sig. value $=$ 0.000). The adjusted R-square is .477. It illustrates that the independent factors explain $47.7 \%$ of the variance of dependent factor (CS). In model 2 (Table 6), Leadership has strongest impact on customer satisfaction $(\beta=0.313)$, follow by continuous improvement towards product design $(\beta=0.285)$, employee involvement towards customer focus $(\beta=0.232)$. 
Table 5. Regression analysis for model 1

\begin{tabular}{|c|c|c|c|c|c|c|c|}
\hline \multirow{2}{*}{$\begin{array}{l}\text { Model } 1 \\
\text { (Adjusted R Square = } \\
.554)\end{array}$} & \multicolumn{2}{|c|}{$\begin{array}{l}\text { Unstandardized } \\
\text { Coefficients }\end{array}$} & \multirow{2}{*}{$\begin{array}{c}\begin{array}{c}\text { Standardized } \\
\text { Coefficients }\end{array} \\
\text { Beta }\end{array}$} & \multirow[t]{2}{*}{$\mathrm{t}$} & \multirow[t]{2}{*}{ Sig. } & \multicolumn{2}{|c|}{$\begin{array}{c}\text { Collinearity } \\
\text { Statistics }\end{array}$} \\
\hline & B & $\begin{array}{l}\text { Std. } \\
\text { Error }\end{array}$ & & & & Tolerance & VIF \\
\hline (Constant) & .600 & .169 & & 3.547 & .000 & & \\
\hline Leadership & .210 & .044 & .249 & 4.791 & .000 & .624 & 1.603 \\
\hline Process management & -.032 & .055 & -.032 & -.586 & .558 & .558 & 1.791 \\
\hline $\begin{array}{l}\text { Education and } \\
\text { training }\end{array}$ & -.008 & .046 & -.008 & -.164 & .870 & .670 & 1.492 \\
\hline $\begin{array}{l}\text { Employee } \\
\text { involvement towards } \\
\text { customer focus }\end{array}$ & .144 & .055 & .135 & 2.599 & .010 & .623 & 1.606 \\
\hline $\begin{array}{l}\text { Continuous } \\
\text { improvement towards } \\
\text { product design }\end{array}$ & .518 & .050 & .536 & 10.320 & .000 & .625 & 1.599 \\
\hline
\end{tabular}

a. Dependent Variable: Productivity and product quality

Table 6. Regression analysis for model 2

\begin{tabular}{|c|c|c|c|c|c|c|c|}
\hline \multirow{2}{*}{$\begin{array}{l}\text { Model } 2 \\
\text { (Adjusted R Square } \\
=.477 \text { ) }\end{array}$} & \multicolumn{2}{|c|}{$\begin{array}{c}\text { Unstandardized } \\
\text { Coefficients }\end{array}$} & \multirow{2}{*}{$\frac{\begin{array}{c}\text { Standardized } \\
\text { Coefficients }\end{array}}{\text { Beta }}$} & \multirow[t]{2}{*}{$\mathrm{t}$} & \multirow[t]{2}{*}{ Sig. } & \multicolumn{2}{|c|}{$\begin{array}{c}\text { Collinearity } \\
\text { Statistics }\end{array}$} \\
\hline & B & Std. Error & & & & Tolerance & VIF \\
\hline (Constant) & .646 & .184 & & 3.505 & .001 & & \\
\hline Leadership & .265 & .048 & .313 & 5.548 & .000 & .624 & 1.603 \\
\hline Process management & .014 & .060 & .014 & .234 & .815 & .558 & 1.791 \\
\hline $\begin{array}{l}\text { Education and } \\
\text { training }\end{array}$ & .038 & .050 & .042 & .765 & .445 & .670 & 1.492 \\
\hline $\begin{array}{l}\text { Employee } \\
\text { involvement towards } \\
\text { customer focus }\end{array}$ & .247 & .060 & .232 & 4.105 & .000 & .623 & 1.606 \\
\hline $\begin{array}{l}\text { Continuous } \\
\text { improvement } \\
\text { towards product } \\
\text { design }\end{array}$ & .276 & .055 & .285 & 5.055 & .000 & .625 & 1.599 \\
\hline
\end{tabular}

a. Dependent Variable: Customer satisfaction 
According to Hair et al. (2006), the criteria used for multicollinearity testing is the VIF in the Collinearity statistic of the independent of variables are higher than 2. The result showed that all the VIFs of two models have value smaller than 2 so there was no multicollinearity in the regression analysis.

\section{Discussion}

The result of the research shows that there are three QMS factors as leadership, employee involvement towards customer focus, and continuous improvement towards product design positively influencing organizational performance as productivity and product quality, customer satisfaction. Two factors as process management and training and education do not positively influence organizational performance.

\section{Leadership (Hla and Hlb are} supported). In this study, leadership positively influences productivity and product quality with standardized coefficient $\beta=0.249$ and on customer satisfaction with $\beta=0.313$. This result confirms again a positive relationship between leadership and organizational performance in the literature review as Samson et al. (1999), Santos et al. (2007), and Jaafreh et al. (2012). In the context of local pharmaceutical manufacturers in Vietnam, the role of top management is very important. The leadership expectation was proven the successful growth in the local company as Savipharm, Imexpharm or Hau Giang factories. The leaders of those companies exposed their leadership high performance behaviors in term of high commitment and deliverable quality mission and vision. By improving the QMS, those companies got the GMP certification from reliable quality association or agency. It is not only building their reputation, but also support them in leading growth in Vietnamese pharmaceutical industry and sustain their business in locally as foundation for exporting which met the international quality standards. Many factories have exposed their impression of leadership by setting the quality mission and vision. They also deeply invest the resources into quality management as well as establishing the Quality Rewards to employees who can achieve the target in quality operation in their organization.

Employee involvement towards customer focus (H4a and H4b are supported). Employee involvement towards customer focus positively influences productivity and product quality with $\beta=0.135$ and on customer satisfaction with $\beta=0.232$. Employee involvement towards customer focus is considered as front line elements to deal with quality and concentrate to customer demand and expectation. The employees involve in usage their knowledge and competency bringing the best service to customer and in development of effective customer relationship. In general, it was found customer focus throughout employee involvement is essential which it proved to have a positive influence on the organizational performance.

Continuous improvement towards product design (H5a and H5b are supported). Continuous improvement towards product design influences productivity and product quality with $\beta=0.536$ and on customer satisfaction with $\beta=0.285$. Continuous improvement towards product design is one of important dimension of quality management in which product design meets or exceeds the requirements and expectations of customers better than the competitors, and then it can lead to an increased market share. The improving product design is required to have research development and marketing experiences. In the pharmaceutical industry, new formulation or new molecule can make different of strategy in term of launch and product pipelines to expand their business. Especially, they can launch the generic products to compete the branded ones as alternative treatment for population and to 
follow the Ministry of Health direction.

Process management ( $\mathrm{H} 2 \mathrm{a}$ and $\mathrm{H} 2 \mathrm{~b}$ are rejected). It is indicated that process management does not positively influence organizational performance. In Vietnamese pharmaceutical industry, the processes and documentation of operating procedures are standardized. Due to sensitive of pharmaceutical formulation influencing safety of human, efficacy of treatment, any changes of the pharmaceutical manufacturing processes will need a huge investment to conduct process validation, qualification of installation, operational, and performance as well as a lot of investment for product research and development. In the other hand, the difficulties of updating new and modern technologies from developed countries into local industry also result in the limitation of process management.

Education and training ( $\mathrm{H} 3 \mathrm{a}$ and $\mathrm{H} 3 \mathrm{~b}$ are rejected). It is indicated that education and training do not positively influence organizational performance. It can be explained that the budget for education and training is the one of constrains for local pharmaceutical manufacturers that they need more external training. They are facing with the high investment to upgrade their organization's knowledge by education and training. In this stage, the objective of training just focus on the basic knowledge mandated for employees running production as GMP requirement rather than concentrating to knowledge and skills to improve quality and productivity and reduce customer complaints.

\section{Conclusion}

The main content of the study is to identify the key factors of QMS influencing organizational performance in Vietnamese pharmaceutical companies. The middle or top managers of 50 factories located in the Southern Vietnam were surveyed and the suitable 265 questionnaires were used to analysis. As a result, the factors as leadership, continuous improvement towards product design, and employee involvement towards customer focus have positively influenced organizational performance (productivity and product quality, customer satisfaction). Two remaining factors as process management, training and education have not positively influenced organizational performance.

Based on the findings of the study, the following managerial implications are suggested to managers of pharmaceutical factories getting GMP in improving performance through enhancing important factors of QMS:

Leadership. The leadership is one of key factors that present the management commitment of the factory towards quality. The quality culture should be built in the organization. The management should take accountability in establishing the quality mission and vision as well as demonstrate the empowerment to employees. The leaders in the company should build the culture of coaching and giving feedback to employee and customer. In addition, management should allocate sufficient resource to support for continuous improvement.

Continuous improvement towards product design. The local pharmaceutical market is requesting the competition mainly depended on the quality of medicine, pricing and productivity. Continuous improvement towards product design is the key factor leading the factories approach the solution effectively. Management should focus on seeking the customer requirements and expectations. Not only focusing on the design, the $R \& D$ procedure and product specification should be frequently reviewed for continuous improvement. Management should motivate and inspire the employee on their achievement in new product development by developing the incentive program and bonus scheme. Management should develop the specific training program concerning research and development to upgrade the scientific 
knowledge for employees. Moreover, customer requirements and production cost should be thoroughly considered during the process of product design as well. Different departments in an organization should participate in new product development. Before production, new product design should be thoroughly reviewed in order to avoid problems happening during production.

Employee involvement towards customer focus. The quality management system addresses how well the organization meets customer requirements and expectations and maintains a good relationship with customers. The management should engage the employees in the factory in building trust to customers by improving the customer service and seeking information related to customer and handling the issue in transparency and integrity. This also emphasizes the employee to discipline ethical code in pharmaceutical industry. Patient focus concept should be expanded to encourage employee engagement towards patient. Empowerment culture should be built up to optimize the contribution and accountability of employees.

The study has certain limitations. Firstly, the scope of this study is focused on pharmaceutical factories in Southern Vietnam. It should be expanded to whole country. Secondly, the study does not include the other industry like cosmetic that have GMP certificate. It is proposed that the next research should be extended to cosmetic industry that its products also impact on human safety, and GMP certificate is also a mandatory requirement of this industry. Lastly, the organizational performance does not consist of financial measurement. Thus, further research is recommended to study the financial indicators to get a general organizational performance.

\section{Acknowledgements}

The author would like to send special thanks to Mr. Dang Anh Vu for his useful insights and supports in completing this paper.

\section{REFERENCES}

Abdullah, M. B. M., Uli, J., \& Tari, J. J. (2009). The relationship of performance with soft factors and quality improvement. Total Quality Management \& Business Excellence, 20(7), 735-748.

Agus, A., Ahmad, M., \& Muhammad, J. (2009). An Empirical Investigation on the Impact of Quality Management on Productivity and Profitability: Associations and Mediating Effect. Contemporary Management Research, 5(1), 77-92.

Ali, M. A. K. \& Talib, A. H. H. (2013). Total Quality Management Approach for Malaysian Food Industry: Conceptual Framework. Journal of Advanced Management Science, 1(4), 405-409.

Antony, J., Leung, K., Knowles, G., \& Gosh, S. (2002). Critical success factors of TQM implementation in Hong Kong industries. International Journal of Quality \& Reliability Management, 19(5), 551-566. doi: 10.1108/02656710210427520.

Arumugam, C. V., Mojtahedzadeh, R., \& Malarvizhi, A. C. (2011). Critical Success Factors of Total Quality Management and their impact on Performance of Iranian Automotive Industry. 2011 International Conference on Innovation, Management and Service IPEDR, 14(33), 312-316. 
Bo Y Te. (2010). Quy Hoach Chi Tiet Phat Trien Cong Nghiep Duoc Viet Nam Giai Doan Den Nam 2020 - Tam Nhin Den Nam 2030.

CERCO. (2000). Handbook for Implementing A Quality Management System In A National Mapping Agency. CERCO Working Group on Quality.

www.eurogeographics.org/sites/default/files/ handbook_V1.pdf

Demirbag, M., Tatoglu, E., Tekinkus, M., \& Zaim, S. (2006). An analysis of the relationship between TQM implementation and organizational performance Evidence from Turkish SMEs. Journal of Manufacturing Technology Management, 17(6), 829-847.

EFQM. (2010). European Foundation Quality Model (EFQM 2010). Retrieved from: http://www.efqm.org (August 17, 2011)

Feng, M., Terziovski, M. \& Samson, D. (2008). Relationship of ISO 9001:2000 quality system certification with operational and business performance: A survey in Australia and New Zealand-based manufacturing and service companies. Journal of Manufacturing Technology Management, 19(1), 22-37.

Flynn, B. B., Schroeder, R. G., \& Sakakibara, S. (1995). The impact of quality management practices on performance and competitive advantage. Decision Sciences, 26, 659-691.

Fynes, B. \& De Búrca, S. (2005). The Effects of Design Quality on Quality Performance. International Journal of Production Economics, 96, 1-14.

Hair, J., Black, W., Babin, B., Anderson, R. \& Tatham, R. (2006). Multivariate Data Analysis, 6th ed. Pearson.

Jaafreh, B. A. \& Al-abedallat, Z. A. (2012). The Effect of Quality Management Practices on Organizational Performance in Jordan: An Empirical Study. International Journal of Financial Research, 4, 9.

Jamali, G., Ebrahimi, M. \& Abbaszadeh, A. M. (2010). TQM Implementation: An Investigation of Critical Success Factors. Education and Management Technology, 2010 International Conference on (ICEMT2010), 112-116.

Jorgensen, B. K. \& Nielsen, F. A. (2013). The effects of TQM Critical Success Factors on Organizational Performance: An empirical study on small and medium sized Danish manufacturing companies. Denmark: Aarhus University.

KAAPS. (2010). King Abdullah II Award for Excellence in the private sector (KAAPS Booklet 2010). Retrieved from: http://www.kaaps.jo/award-criteria (August 25, 2011)

Kanapathy, K. \& Khan, K. (2012). Assessing the relationship between ITIL implementation progress and firm size: evidence from Malaysia. International Journal of Business and Management, 7 (2), 194

Kanapathy, K. (2008). Critical factors of quality management used in research questionnaires: a review of literature. Sunway Academic Journal, 5, 19-30.

Kaynak, H. (2003) The relationship between TQM practices and their effects on firm performance. Journal of Operations Management, 21(4), 405-435. 
Lee, P. \& Quazi, A. H. (2001). A methodology for developing a self-assessment tool to measure quality performance in organizations. International Journal of Quality \& Reliability Management, 18(2), 118-141.

Nekoueizadeh, S. \& Esmaeili, S. (2013). A study of the impact of TQM on organizational performance of the Telecommunication Industry in Iran. European Online Journal of Natural and Social Sciences, 2(3), 968-978.

Nguyen, T. Q. L. (2004). Improving Performance through Linking IT with TQM. Journal of Science and Technology Development of Vietnam National University-Ho Chi Minh City, 7, 90-98.

Samson, D. \& Terziovski, M. (1999). The relationship between total quality management practices and operational performance. Journal of Operations Management, 17(4), 393409.

Santos-Vijande, L., M., \& Alvarez-Gonzales, I., L. (2007). TQM and firms performance: An EFQM excellence model research based survey. Int. Journal of Business Science and Applied Management, 2(2), 21-41.

Saraph, V. J., Benson, G. P., \& Schroeder, G. R. (1989). A Instrument for measuring the Critical factors of Quality management. Decision Sciences, 20(4), 810-829.

Schlickman, J. (2003), ISO 9001:2000: Quality management system design. Norwood: Artech House, Inc.

Talib, F., Rahman, Z., \& Qureshi, N., M. (2010). The relationship between total quality management and quality performance in the service industry: a theoretical model. International Journal of Business, Management and Social Sciences, 1(1), 113-128.

Udegbe, E. S. \& Udegbe, I. M. (2013). Impact Of Product Development And Innovation On Organisational Performance. International Journal Of Management And Sustainability, 2(12), 220-230.

World Health Organization. (2007). Quality assurance of pharmaceuticals. A compendium of guidelines and related materials, (2 $2^{\text {nd }}$ ed.). ISBN 9789241547086.

Yuparkon, A., Laohavichien, T., Rassameethe, B., \& Meeampol, S. (2013). Critical Success Factors of TQM in Thailand: A Literature Review and TQM Implementation Approach. International Journal of Business Development and Research, 1(1), 38-63.

Zhang, Z., Waszink, A., \& Wijngaard, J. (1999). An instrument for measuring TQM implementation for Chinese manufacturing companies. International Journal of Quality \& Reliability Management, 17(7), 730-755. Doi 10.1108/02656710010315247. 